\title{
A new deep-sea pennatulacean (Anthozoa: Octocorallia: Chunellidae) from the Porcupine Abyssal Plain (NE Atlantic)
}

\author{
Pablo J. López-González • Gary C. Williams
}

Received: 24 July 2009/Revised: 18 August 2010/Accepted: 5 September 2010/Published online: 30 October 2010

(C) Springer-Verlag and AWI 2010

\begin{abstract}
During the BENGAL cruises, an important collection of deep-sea benthic organisms was sampled. Among the pennatulacean colonies, a previously undescribed species of chunellid was collected. That material is here described as the type species of a new genus, Porcupinella gen. nov. The new genus and species are described based on material collected in the Porcupine Abyssal Plain (NE Atlantic), 4,839-4,847 $\mathrm{m}$ in depth. This is the first time that a chunellid is reported from the Atlantic Ocean. The new genus is compared with the other genera in the family, and some phylogenetic remarks about the families Chunellidae and Umbellulidae are also provided.
\end{abstract}

Keywords North Atlantic - Deep sea - New species · Pennatulacea $\cdot$ Octocoral

\section{Introduction}

The anthozoan fauna from deep-sea zones is still poorly known, although some recent international efforts have

Communicated by Peter Funch.

P. J. López-González ( $₫)$

Biodiversidad y Ecología de Invertebrados Marinos,

Departamento de Fisiología y Zoología, Facultad de Biología,

Universidad de Sevilla, Reina Mercedes 6, 41012 Sevilla, Spain

e-mail: pjlopez@us.es

\section{G. C. Williams}

Department of Invertebrate Zoology and Geology,

California Academy of Sciences, 55 Music Concourse Drive,

Golden Gate Park, San Francisco, CA 94118-4503, USA

e-mail: gwilliams@calacademy.org tried to improve our general knowledge of the diversity and ecology of deep-sea benthic communities. One of these efforts was the BENGAL (high-resolution temporal and spatial study of the BENthic biology and Geochemistry of a north-eastern Atlantic abyssal locality).

The pennatulaceans are one of the most distinguishable anthozoan groups in the deep sea. This octocoral order includes more than 200 species in 34 genera and 14 families (Williams 1995a, López-González et al. 2002, LópezGonzález and Williams 2002). Based on morphological characters, the families Veretillidae and Echinoptiidae are considered the least derived, being distributed in relatively shallow waters $(<320 \mathrm{~m}$ in depth for Veretillidae and $<630 \mathrm{~m}$ for Echinoptilidae), while a great variety of derived forms are present with unrestricted bathymetric ranges. Other well-known forms like Halipteridae and Virgulariidae have species distributed $<2,000 \mathrm{~m}$, whereas members of Funiculinidae, Pennatulidae and Anthoptilidae can be found in $<3,200 \mathrm{~m}$. Species belonging to the families Kophobelemnidae, Protoptilidae and Scleroptilidae are among the deeper sea pens $(<4,400 \mathrm{~m})$, while the monogeneric pennatulacean family, Umbellulidae, has been recorded in benthic deeper $>6,000 \mathrm{~m}$. It has been postulated that pennatulaceans initially differentiated in shallow waters of tropical oceans and diversified and dispersed to all depths of the temperate and polar regions as well as tropical seas (Williams 1993, 1997).

During the BENGAL cruises, an undescribed genus and species of pennatulacean octocoral was discovered. The new taxon is here allocated to the family Chunellidae Kükenthal 1902. This material is described, and its relationships with the other genera in the family, Chunella Kükenthal 1902 and Amphiacme Kükenthal 1903, as well as the genus Calibelemnon Nutting 1908, are discussed. The genera currently included in the family 
Chunellidae are considered derived sea pens, until now present in a moderately deep bathymetric range (812$1,200 \mathrm{~m})$. The new chunellid genus described here has been found in depths ranging 4,510-5,300 $\mathrm{m}$, being the second deepest pennatulacean genus known, after Umbellula Cuvier, 1797. Some phylogenetic remarks about the families Chunellidae and Umbellulidae are also provided.

\section{Materials and methods}

Field work of the BENGAL programme started with a month-long cruise on the R.R.S. Discovery in September 1996. Five additional cruises were carried out on the same researchship during 1997 and 1998. Four of the six cruises provided benthic macrofauna, all of them using a bottom trawl. The number of sampled stations varied over the different cruises: BENGAL 2 (5 stations), BENGAL 3 (4 stations), BENGAL 5 (4 stations) and BENGAL 6 (2 stations). In total, 15 stations were sampled for benthic macrofauna during these four BENGAL cruises.

The material here studied was collected during the BENGAL cruises: 2 (Discovery cruise 226, 12 Mar-10 Apr 1997, principal scientist: A.L. Rice, Challenger Division for Seafloor Processes, Southampton Oceanographic Centre, U.K.), 3 (Discovery cruise 229, 2-31 Jul 1997, principal scientist: B.J. Bett, Challenger Division for Sea floor Processes, Southampton Oceanographic Centre, U.K.), 5 (Discovery cruise 231, 1-31 Mar 1998, principal scientist: A.L. Rice, Challenger Division for Sea floor Processes, Southampton Oceanographic Centre, U.K.) and 6 (Discovery cruise 237,25 Sep-8 Oct 1998, principal scientist: M. Sibuet, IFREMER, Centre de Brest, DRO/Environnment Profond, France).

The megafauna collected by the IFREMER team was obtained using a bottom trawl (chalut à perche, IFREMER). The bottom trawl consisted of a wooden 6-m-long beam attached to two solid 1-m-high iron shoes. The mesh size decreased from 2 to $1 \mathrm{~cm}$.

All the specimens larger than $1 \mathrm{~cm}$ were sorted, counted and weighed on board. Some of them were dissected on board for biological purposes; the others were preserved in $3 \%$ borax-buffered formaldehyde. In the laboratory at IFREMER, fixed specimens were washed with seawater and then transferred into 70\% ethanol. Colony and sclerite terminology follow Bayer et al. (1983). The material studied has been deposited in the Muséum national d'Histoire Naturelle (MNHN) in Paris, in the California Academy of Sciences in San Francisco (CAS) and in the Anthozoan reference collection of the research group
"Biodiversidad y Ecología de Invertebrados Marinos" of the University of Seville (BEIM).

\section{Results}

Chunellidae Kükenthal 1902

Chunellidae Kükenthal 1902: 302; Jungersen 1904: 9; Balss 1910: 9; Kükenthal and Broch 1911: 270; Kükenthal 1915: 44; Hickson 1916: 106; Williams 1990: 76; Williams,1995a: 115.

Diagnosis (modified from Kükenthal 1915: 44 and Williams 1990: 76, modifications in italic).

Colonies slender, with rachis bilaterally symmetrical. Axis quadrangular, present along the entire length of the colony. Polyp leaves absent. Autozooids in pairs or in whorls of 3-4 polyps, pairs or whorls usually well separated, but sometimes secondary autozooids grouped together forming a cluster-like arrangement. A ventrally oriented terminal autozooid separated by a bare space of rachis is present (either functional or rudimentary). Autozooids without calyces. Siphonozooids few and inconspicuous, on rachis between autozooids. Sclerites completely absent or with small bodies restricted to the peduncle.

Nominal genera

Chunella Kükenthal, 1902; Amphiacme Kükenthal, 1903; Porcupinella gen. nov.

The genus Calibelemnon Nutting, 1908 is here considered a member of the family Scleroptilidae and not the family Chunellidae due to the possession of numerous longitudinally arranged polyps that do not form clusters and the lack of a terminal autozooid.

Porcupinella, gen. nov.

\section{Diagnosis}

Colonies elongate and delicate. Rachis bilaterally symmetrical. Axis present throughout colony, quadrangular in cross section. Terminal autozooid well developed, ventrally oriented, separated by bare interval of rachis from the rest of polyps, bilaterally symmetrical to somewhat asymmetrical. Autozooids arranged in 2-3 pairs (last may be incomplete) grouped on the rachis, forming a pseudocluster, younger polyps arising on ventral side of the rachis, between the basis of previous pairs. Anthocodiae nonretractile. Calyces absent. Siphonozooids minute, situated on the rachis close to the basis of the autozooids. Sclerites absent except for minute ovals of the peduncular interior. 
Etymology

The generic name is derived from the geographical area, the Porcupine Abyssal Plain, where the new taxon was discovered. Gender feminine.

\section{Type species}

Porcupinella profunda sp. nov. here designated by monotypy.

\section{Comparison with other taxa}

Porcupinella, gen. nov. is here included within the Chunellidae due to the presence of the following combination of characters: (1) adjacent polyps free, not fused to any degree; (2) colonies elongate and rachis erect; (3) autozooids relatively few and arranged biserially along rachis, with a naked dorsal tract along entire length of rachis; (4) rachis without sclerites and polyps without calyces; (5) with a terminal autozooid.

With the discovery of Porcupinella, the list of diagnostic characters of the family Chunellidae (Kükenthal 1915: 44; Williams 1990: 76) need only be slightly modified to include the differential features between Porcupinella and the remaining genera in the family.

The presence in Porcupinella of a terminal autozooid ventrally oriented is also shared by Chunella and Amphiacme. However, the reduction in the bare space of rachis between the different paired autozooids, giving the false impression of a cluster similar to that observed in the genus Umbellula Gray, 1870 (Fam. Umbellulidae), is a distinctive character for Porcupinella. The presence of a bare space of rachis between the terminal autozooid and the crowded group of paired autozooid clearly places Porcupinella within the Chunellidae. The addition of young autozooids in the ventral space of the first pair (whorl) of autozooids reinforces the consideration of the space of separation between the terminal ventrally oriented autozooid and the rest of the autozooids as a consistent character to be used in the familiar placement of the new genus.

Porcupinella profunda sp. nov. (Figs. 1, 2, 3, 4 and 5).

Umbellula carpenteri, Broch, 1957: 357 (in part); Dolan, 2008: 71 (in part).

\section{Material examined}

Type material: MNHN-IK.2009-0800, holotype, Bengal 3 cruise, Discovery 229, stn. 13200 \# 93, one whole colony $48 \mathrm{~mm}$ length, and MNHN-IK.2009-0801, paratype, with the same sampling data as the holotype, one whole colony $39 \mathrm{~mm}$ length.
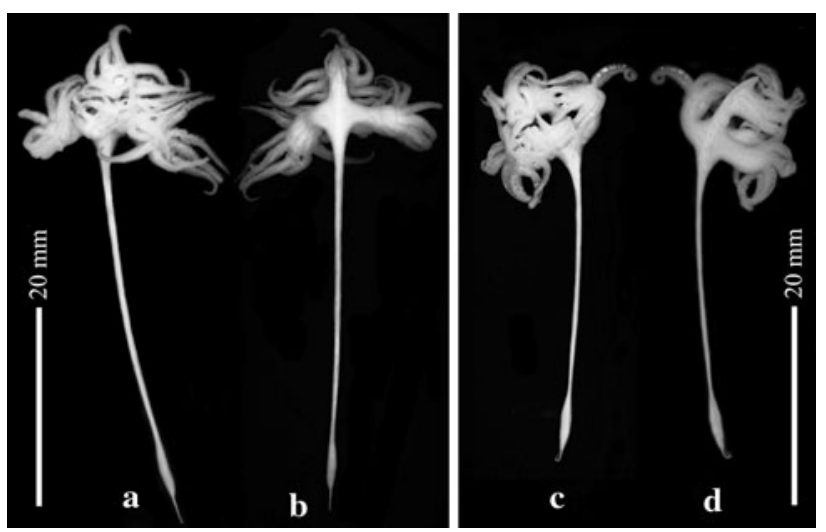

Fig. 1 Porcupinella profunda gen. nov. and sp. nov. Holotype. a Whole colony, ventral view. b Whole colony, dorsal view. Paratype. c Whole colony, ventral view. d Whole colony, dorsal view. Notice the wide bare space between the odd terminal polyps and the groups of pairs (secondary polyps)

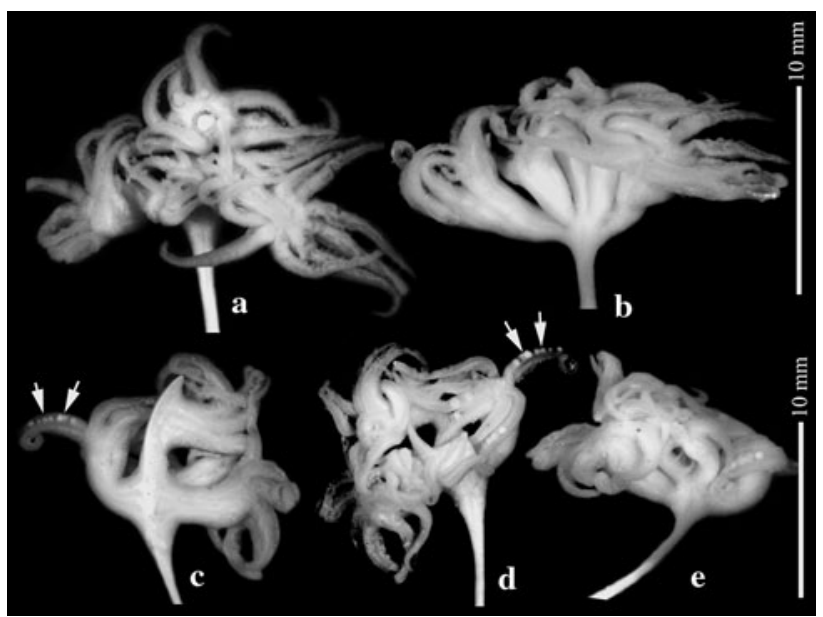

Fig. 2 Porcupinella profunda gen. nov. and sp. nov. Holotype. a Detail from ventral view. b Detail of the basal part of secondary polyps, view from inferior part of the colony, notice different diameter of the polyps from outer to inner ventral part, and the existence of two pairs and a odd internal polyp. Paratype. c Detail from dorsal view. d Detail from ventral view. e Detail of the basal part of secondary polyps, view from inferior part of the colony, notice the existence of two pairs of secondary polyps of different diameters, and the presence of free spermatic cysts (as white spherical structures arrowed) visible at the interior of the tentacles cavities

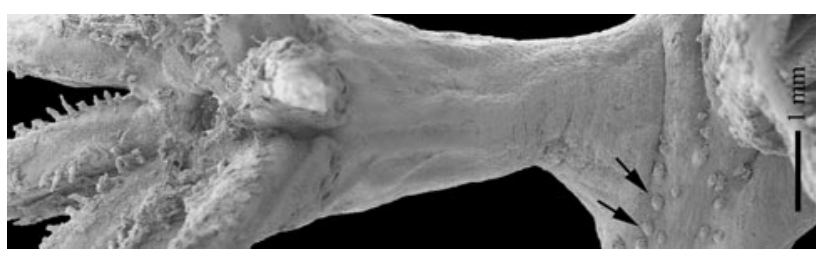

Fig. 3 Porcupinella profunda gen. nov. and sp. nov. SEM, lateral polyp showing tentacles and mouth, and several siphonozooids on rachis (arrowed) 


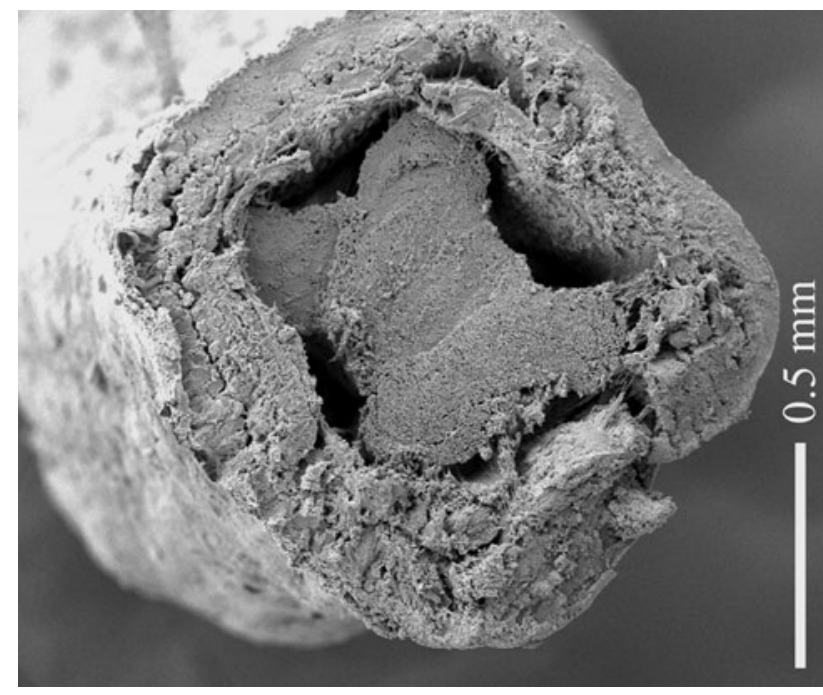

Fig. 4 Porcupinella profunda gen. nov. and sp. nov. SEM, transversal section of peduncle showing the $x$-shaped axis

Additional material:

MNHN-IK.2009-0802, Bengal 2 cruise, Discovery 226, stn. 13078 \# 27, one whole colony; BEIM-CRO-0017, Bengal 3 cruise, Discovery 229, stn. 13200 \# 70, two whole colonies; MNHN-IK.2009-0803, Bengal 3 cruise, Discovery 229, stn. 13200 \# 93, one whole colony; MNHN-IK.20090804, Bengal 3 cruise, Discovery 229, stn. 13200 \# 94, four whole colonies; BEIM-CRO-0018a, Bengal 3 cruise, Discovery 229, stn. 13200 \# 94, two whole colonies; MNHNIK.2009-0805, Bengal 5 cruise, Discovery 231, stn. 13368 \# 48, two whole colonies; CASIZ-180424, Bengal 5 cruise,
Discovery 231, stn. 13368 \# 48, two whole colonies; MNHN-IK.2009-0806, Bengal 5 cruise, Discovery 231, stn. 13368 \# 52, one whole colonies; BEIM-CRO-0018b, Bengal 5 cruise, Discovery 231, stn. 13368 \# 52, two whole colonies; CASIZ-180425, Bengal 5 cruise, Discovery 231, stn. 13368 \# 52, two whole colonies; MNHN-IK.20090807, Bengal 6 cruise, Discovery 237, stn. 13627 \# 11, one whole colony; CASIZ-180426, Bengal 6 cruise, Discovery 237, stn. 13627 \# 11, two whole colonies; MNHN-IK. 2009-0808, Bengal 6 cruise, Discovery 237, stn. 13627 \# 24 , one whole colony.

All sampling data are summarized in Table 1.

\section{Diagnosis}

As for the genus.

\section{Description}

External anatomy The colonies are delicate, elongate and slightly clavate due to the distal concentration of polyps; preserved colony length is $30-48 \mathrm{~mm}$. The rachis is $8.5-12 \mathrm{~mm}$ long (about $26 \%$ of colony length) and $2 \mathrm{~mm}$ wide at bare rachis space under terminal autozooid. The peduncle is $21.5-37 \mathrm{~mm}$ long (about $74 \%$ of colony length) and $1.2 \mathrm{~mm}$ wide at widest point (proximal muscular ampulla). The axis is present throughout colony, $\mathrm{x}$-shaped in cross section, $0.85-0.6 \mathrm{~mm}$ wide. The rachis is bilateral throughout. Autozooids are not numerous, but relatively large, up to $6 \mathrm{~mm}$ long and $3.5 \mathrm{~mm}$ wide. The anthocodiae are non-retractile, and calyces are completely absent. The tentacles are approximately $9 \mathrm{~mm}$ long in
Fig. 5 Porcupinella profunda gen. nov and sp. nov. Paratype. a One of the tentacles cut off from the paratype colony in Fig. $3 \mathrm{c}$ and d (tentacle arrowed) showing spherical spermatic cysts. b Histological section along the tentacular axis showing a series of spermatic cysts. c Detail from two spertamic cysts showing sperm heads
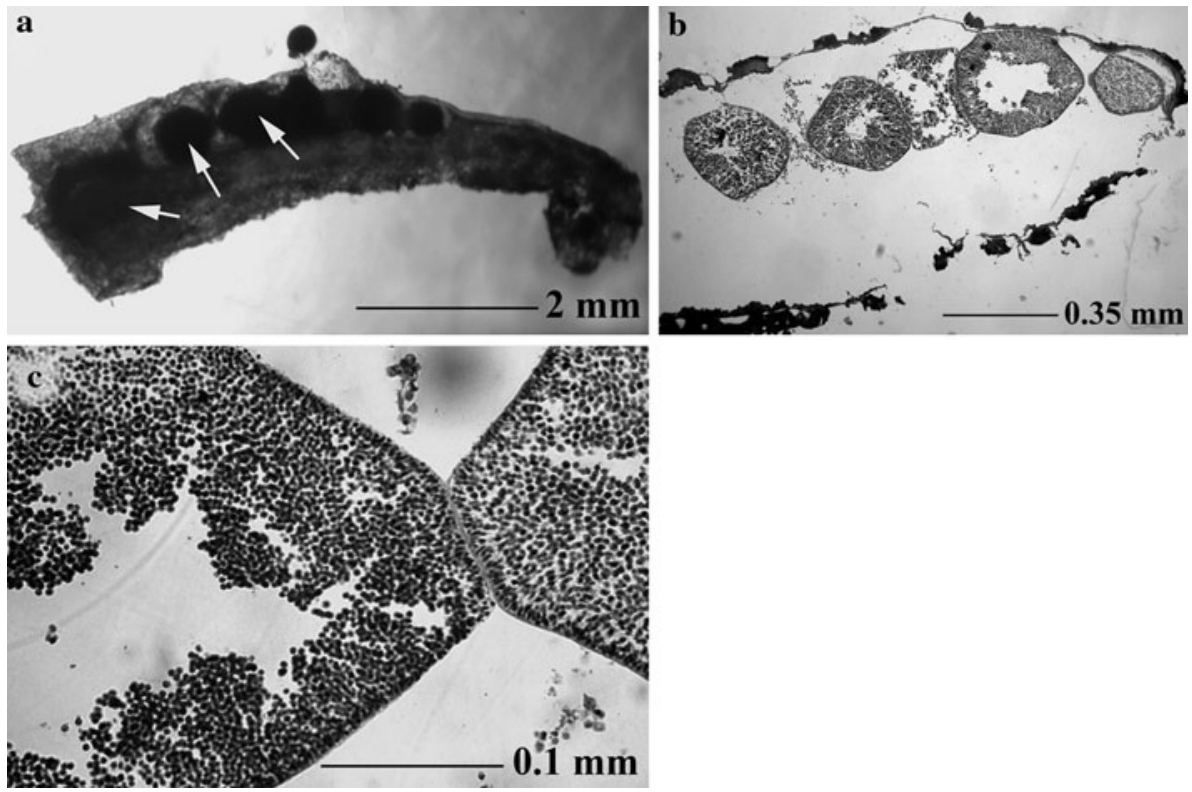
Table 1 List of stations which procured pennatulacean specimens during BENGAL cruises, with indication of sampling data, pennatulacean species and (between parenthesis) number of colonies collected in each station

\begin{tabular}{|c|c|c|c|c|c|}
\hline Cruise & Station & Date & Coordinates & Depth (m) & $\begin{array}{l}\text { Species (number of } \\
\text { colonies collected) }\end{array}$ \\
\hline \multirow[t]{3}{*}{ BENGAL-2 (Discovery 226) } & 13078 \# 06 & $30 / 04 / 1997$ & $48^{\circ} 44.55^{\prime} \mathrm{N} 16^{\circ} 32.77^{\prime} \mathrm{W}$ & 4,838 & Kophobelemnon sp. (1) \\
\hline & 13078 \# 11 & 01/04/1997 & $48^{\circ} 53.19^{\prime} \mathrm{N} 16^{\circ} 35.98^{\prime} \mathrm{W}$ & 4,844 & Kophobelemnon sp. (1) \\
\hline & 13078 \# 27 & 03/04/1997 & $48^{\circ} 47.26^{\prime} \mathrm{N} 16^{\circ} 34.01^{\prime} \mathrm{W}$ & 4,844 & Porcupinella profunda (1) \\
\hline \multirow[t]{3}{*}{ BENGAL-3 (Discovery 229) } & $13200 \# 70$ & 20/07/1997 & $48^{\circ} 51.62^{\prime} \mathrm{N} 16^{\circ} 31.80^{\prime} \mathrm{W}$ & 4,845 & $\begin{array}{l}\text { Kophobelemnon sp. (1) } \\
\text { Porcupinella profunda (2) }\end{array}$ \\
\hline & 13200 \# 93 & 25/07/1997 & $48^{\circ} 50.55^{\prime} \mathrm{N} 16^{\circ} 25.30^{\prime} \mathrm{W}$ & 4,844 & Porcupinella profunda (3) \\
\hline & 13200 \# 94 & 25/07/1997 & $48^{\circ} 50.99^{\prime} \mathrm{N} 16^{\circ} 26.03^{\prime} \mathrm{W}$ & 4,847 & $\begin{array}{l}\text { Kophobelemnon sp. (7) } \\
\text { Porcupinella profunda (6) } \\
\text { Umbellula monocephalus (3) }\end{array}$ \\
\hline \multirow[t]{4}{*}{ BENGAL-5 (Discovery 231) } & $13368 \# 47$ & $16 / 03 / 1998$ & $48^{\circ} 51.63^{\prime} \mathrm{N} 16^{\circ} 25.18^{\prime} \mathrm{W}$ & 4,844 & Kophobelemnon sp. (1) \\
\hline & $13368 \# 48$ & $17 / 03 / 1998$ & $48^{\circ} 49.64^{\prime} \mathrm{N} 16^{\circ} 30.12^{\prime} \mathrm{W}$ & 4,841 & $\begin{array}{l}\text { Kophobelmnon sp. (4) } \\
\text { Porcupinella profunda (4) } \\
\text { Umbellula monocephalus (2) }\end{array}$ \\
\hline & 13368 \# 52 & $19 / 03 / 1998$ & $48^{\circ} 48.30^{\prime} \mathrm{N} 16^{\circ} 25.97^{\prime} \mathrm{W}$ & 4,839 & $\begin{array}{l}\text { Kophobelemnon sp. (2) } \\
\text { Porcupinella profunda (5) }\end{array}$ \\
\hline & 13368 \# 53 & 19/03/1998 & $48^{\circ} 49.98^{\prime} \mathrm{N} 16^{\circ} 33.53^{\prime} \mathrm{W}$ & 4,842 & $\begin{array}{l}\text { Kophobelemnon sp. (2) } \\
\text { Umbellula monocephalus }(1)\end{array}$ \\
\hline \multirow[t]{2}{*}{ BENGAL-6 (Discovery 237) } & 13627 \# 11 & 01/10/1998 & $48^{\circ} 47.82^{\prime} \mathrm{N} 16^{\circ} 40.37^{\prime} \mathrm{W}$ & 4,847 & $\begin{array}{l}\text { Kophobelemnon sp. (1) } \\
\text { Porcupinella profunda }(3)\end{array}$ \\
\hline & 13627 \# 24 & 05/10/1998 & $48^{\circ} 50.47^{\prime} \mathrm{N} 16^{\circ} 44.37^{\prime} \mathrm{W}$ & 4,840 & $\begin{array}{l}\text { Kophobelemnon sp. (2) } \\
\text { Porcupinella profunda (1) } \\
\text { Umbellula monocephalus (1) }\end{array}$ \\
\hline
\end{tabular}

preserved state, with one row of about $15-17$ pinnules on each side. The autozooids are arranged in $2-3$ pairs (last may be incomplete) grouped on the rachis, forming a cluster-like arrangement. The youngest pair of autozooids arising ventrally on the rachis, between the basis of previous pair. The youngest autozooids are clearly smaller in diameter than oldest pairs. The terminal autozooid is well developed, ventrally oriented and bilaterally symmetrical. The terminal autozooid is separated by a bare interval of rachis from the rest of polyps. The siphonozooids are scarce and minute, situated on the rachis, under the group of secondary autozooids, and between this group and the terminal autozooid.

Internal anatomy The gastric cavities of the autozooids are relatively short, tubular in shape and $4-5 \mathrm{~mm}$ in length and $1.8-2.2 \mathrm{~mm}$ in width. The autozooid body wall is $0.5-0.7 \mathrm{~mm}$ in width. The peduncle has four internal longitudinal canals.

Sclerites The sclerites are completely absent except for minute colourless ovals of the peduncular interior.

Colour Preserved examined colonies are yellowish in ethanol.

\section{Remarks on the development of polyps and maturity} in Porcupinella

Porcupinella profunda sp. nov. is a delicate and small sea pen when compared with other representatives of the order such as some species of the genus Umbellula Cuvier, 1798 or Distichoptilum Verrill, 1882 that can reach more than one metre in length (Williams 1990; López-González, pers. observ.). The 25 colonies examined ranged from 30 to $48 \mathrm{~mm}$ in length. In all these colonies, a terminal ventrally oriented autozooid is clearly separated from the larger pair of lateral autozooids. The number of smaller autozooids found between the ventral basis of the lateral pair of autozooids can be one ( 5 colonies), two ( 19 colonies) or three (1 colony). Although a slight asynchrony in the development of the ventral pairs of polyps apparently exists, both sister polyps (here considering the two polyps as a pair) grow to reach the same size, always being smaller in size than the polyps belonging to the previous pair. The maximum diameters of terminal, lateral and ventral autozooids have been measured for each colony, considering the size of both sister polyps separately when it is clearly different. Table 2 shows the average, the standard deviation and the 
Table 2 Porcupinella profunda gen. nov. et sp. nov

\begin{tabular}{llllll}
\hline & $\begin{array}{l}\text { Colonial size } \\
(\mathrm{mm})\end{array}$ & $\begin{array}{l}\text { Terminal autozooid } \\
(\varnothing \mathrm{mm})\end{array}$ & $\begin{array}{l}\text { First pair of lateral } \\
\text { autozooid }(\varnothing \mathrm{mm})\end{array}$ & $\begin{array}{l}\text { Second pair of lateral } \\
\text { autozoois }(\varnothing \mathrm{mm})\end{array}$ & $\begin{array}{l}\text { Third pair of lateral } \\
\text { autozooids }(\varnothing \mathrm{mm})\end{array}$ \\
\hline Average $( \pm \mathrm{SD})$ & - & $3.23( \pm 0.29)$ & $3.25( \pm 0.25)$ & $2.29 *( \pm 0.29)$ & - \\
Maximum & 48 & 3.8 & 3.7 & 2.7 & 2.2 \\
Minimum & 30 & 2.7 & 2.8 & $1.6 *$ & 2.2 \\
$N$ & 25 & 25 & 25 & 25 & 1 \\
\hline
\end{tabular}

Summary of colonial and polyps measurements from all the material examined ( 25 colonies in total). Asterisk means that only the maximum values in each pair of polyps (when their diameters are different) have been used

maximum and minimum values for these measurements. After the analysis of these data, it is clear that: 1) the first pair of lateral autozooids grows to reach a similar size to the odd ventrally oriented autozooid; 2) there exists a clear decrease in the size of paired autozooids from the lateral to the more internal ones (maximum values 3.7 for the lateral, 2.7 for the first ventral and 2.2 for the second ventral); 3 ) there exists a slight asynchrony in the development of the sister polyps, only observed in the ventral pairs, the terminal autozooid and lateral pair are always fully developed (in 5 of the 25 colonies examined sister polyps are slightly different in size, and in the only colony with a second ventral pair of polyps-the holotype-, this is incomplete with only one small polyp of $2.2 \mathrm{~mm}$ ).

On the other hand, the colonies examined showed large reproductive products of up to $0.6 \mathrm{~mm}$ in diameter, clearly identifiable due to transparency in the base of the tentacles (see Fig. 5) and after dissection in the gastrovascular cavities of the polyps.

Etymology

The species name, profunda (from the Latin, profundus, for "deep or of the depths"), is chosen because this taxon is one of the deepest octocoral species described and the second deepest pennatulacean genus.

Geographical and depth distribution

At present, Porcupinella profunda sp. nov. is known from the deep sea of the North Atlantic [Porcupine Abyssal Plain, $\mathrm{NE}$ Atlantic (around $48^{\circ} 50^{\prime} \mathrm{N} 16^{\circ} \mathrm{W}$ ) to equatorial latitudes $\left(1^{\circ} 03^{\prime} \mathrm{N} 18^{\circ} 40^{\prime} \mathrm{W}\right)$ ] (Fig. 6), from 4,510 to 5,300 $\mathrm{m}$ in depth (Broch 1957; Dolan 2008 as Umbellula carpenteri, and present account see "Discussion"). This is the first time that a chunellid has been reported from the Atlantic Ocean.

Other pennatulacean species collected on BENGAL cruises

Twelve of the 15 sampled stations during the BENGAL programme in the Porcupine abyssal plain provided

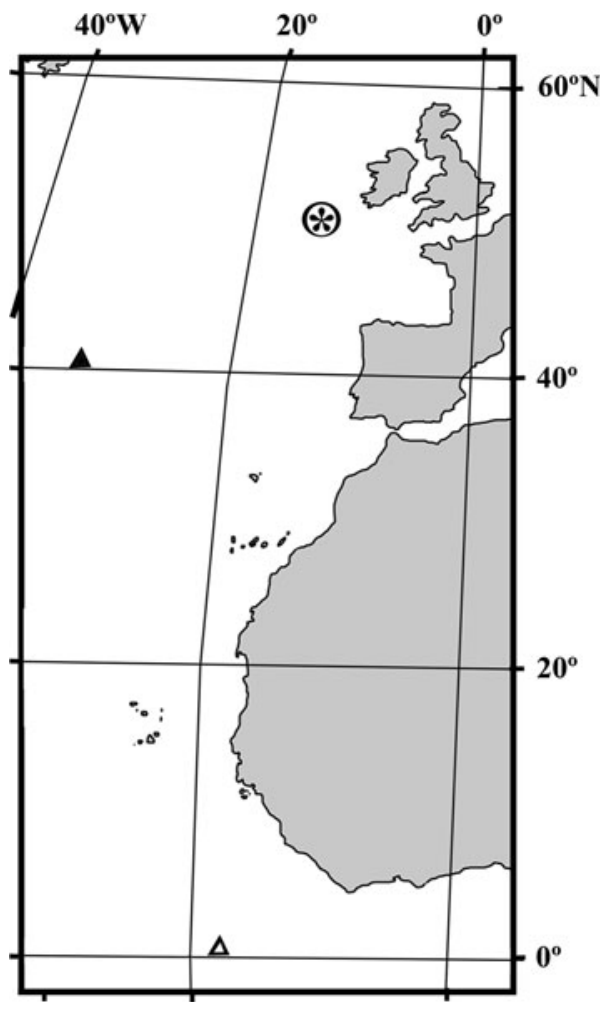

Fig. 6 Known distribution of Porcupinella profunda gen. nov. and sp. nov; Broch 1957 (open triangle haul no. 4; solid triangle: haul no. 3), Dolan 2008 (circle), present paper (asterisk). Dolan's and present material came from the same area, the Porcupine Abyssal Plain

pennatulacean octocorals. Only three pennatulacean species were present in the catches: Porcupinella profunda $(25$ colonies from 8 sampling stations), Umbellula monocephalus Pasternak, 1975 (7 colonies from 4 sampling stations), and Kophobelmnon sp. (22 colonies from 10 sampling stations). The specimens of the genus Kophobelemnon will be studied in a further contribution dedicated exclusively to this genus from different geographical areas (López-González, in prep.). Table 2 summarizes sampling stations, pennatulacean species and number of colonies collected at each station. No other pennatulacean specimens were present in the catch. 


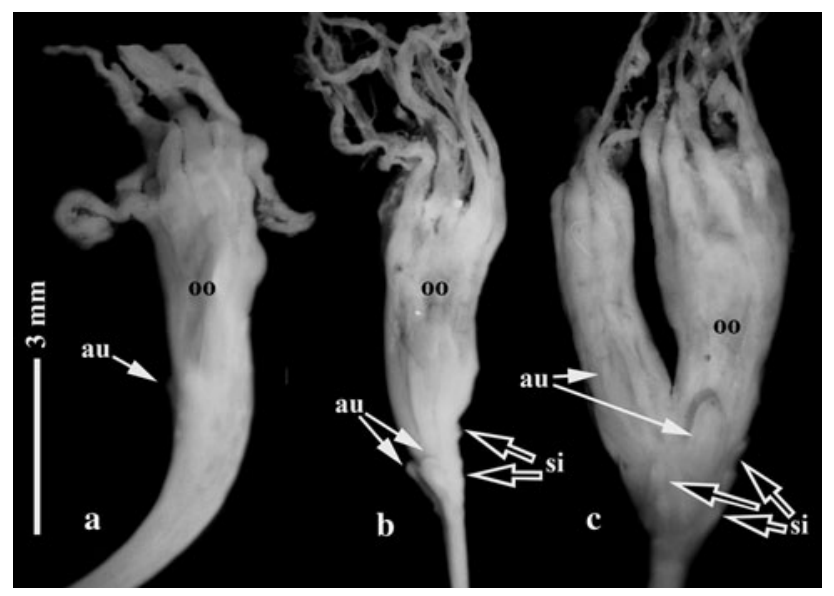

Fig. 7 Early developmental stages of Umbellula encrinus colonies from BIOICE program. a Young colony with large oozoid (oo) and incipient autozooids $(a u)$. b Young colony with large oozoid, distinct incipient autozooids and siphonozooids $(s i)$. c Young colony with large oozoid, and autozooids with different growth rate, one of them with developed tentacles, while the other remains as a distinct mound; siphonozooids are distinct as minute verrucae on the surface of the incipient common distal rachis body joining the bases of large zooids

\section{Discussion}

Comparisons between Porcupinella and Umbellula from an ontogenetic point of view

The numbers of colonies examined, the consistency of the morphological features described and the presence of mature colonies demonstrate that Porcupinella cannot be confused with young colonies of Umbellula. For comparative purposes, the first stages of Umbellula encrinus (Linnaeus 1758) have been examined and illustrated (Fig. 7). At the first stage, the terminal zooids produce two small processes (future secondary autozooids) on the ventral proximal part (stage 1). The synchronic growth of the basal processes and the distinctive presence of a few siphonozooids also on the proximal part of the terminal polyps characterize another stage (stage 2). Finally, a clear asynchrony in the development of the first pair of secondary autozooids is produced, the siphonozooids being more distinct on the proximal part of the fused group of polyps (stage 3 ). In this ontogenetic development, we can observe that in Umbellula, secondary autozooids definitely grow on the proximal part of the terminal autozooids; siphonozooids become more numerous during these ontogenetic processes and moreover on the body of the terminal autozooids. In contrast, in Porcupinella, the first pair of secondary and lateral autozooids are clearly separated from the body of the ventrally oriented terminal autozooids, and the siphonozooids are present on the bare space between autozooids.
Comparison with other taxa previously reported in the North Atlantic

As commented above, although Porcupinella profunda gen. and sp. nov. is a chunellid, it can be confused by the general appearance with young specimens of species of the genus Umbellula. Taking into account this possibility, if we consult the previous records in the literature of Umbellula species in the North Atlantic, it can be noticed that Porcupinella has been collected, examined and reported under an Umbellula species on at least two occasions.

First, Broch (1957: 357, Pl. I, figs. 2-4) identified Umbellula carpenteri Kölliker, 1880 from the mid-Atlantic Ocean. Part of this material clearly corresponds with Porcupinella profunda n. sp. Broch (1957) reported $U$. carpenteri at two stations in the North Atlantic (station 342 (Haul No. 4) $01^{\circ} 03^{\prime} \mathrm{N} 18^{\circ} 40^{\prime} \mathrm{W}-00^{\circ} 58^{\prime} \mathrm{N} 18^{\circ} 37^{\prime} \mathrm{W}$, 5,250-5,300 m, 7 specimens; and station 387 (Haul No. 13), $40^{\circ} 33^{\prime} \mathrm{N} 35^{\circ} 24^{\prime} \mathrm{W}-40^{\circ} 34^{\prime} \mathrm{N} 35^{\circ} 52^{\prime} \mathrm{W}, 4,600-4,540 \mathrm{~m}$, 9 specimens). As described by Broch, two sets of specimens were found, the smaller ones considered by him as young colonies, are attributable to Porcupinella (see Broch 1957: Text-figs 4i to iii, and Plate I, figs. 2-4), while the larger colonies, considered by Broch as "a little aberrant" correspond with Umbellula specimens (see Broch 1957: Text-figs 4iv to vii). However, these do not agree with the original description of Umbellula carpenteri given by Kölliker (1880), as well as that of subsequent authors (see Pasternak 1962: 125).

More recently, Dolan (2008) carried out a monographic work for her unpublished $\mathrm{PhD}$ dissertation on the phylogenetics, systematics and biogeography of deep-sea pennatulaceans based on molecular and morphological characters. In this revision, the genus Umbellula was the core of the study, reporting a total of four species (U. carpenteri, U. huxley, U. monocephalus and U. thomsoni) from the Porcupine Abyssal Plain. It is likely that Dolan based her identifications on the text and illustrations of Broch and agreed that Umbellula carpenteri is present in the Porcupine Abyssal Plain at 4,510-4,860 m depth. Her examined material came from the north-east Atlantic (Porcupine Abyssal Plain) and South Indian Ocean (Crozet Islands, SubAntarctic). The Atlantic material examined by Dolan is Porcupinella profunda gen. and sp. nov., while the South Indian Ocean material clearly represents a species of Umbellula. It is noteworthy to mention that all molecular approaches by Dolan involving her Umbellula carpenteri were carried out using the South Indian material, where it clustered with other Umbellula congeners.

On the other hand, Umbellula carpenteri was originally based on material collected from Antarctic waters $\left(62^{\circ} 26^{\prime} \mathrm{S}\right.$ $95^{\circ} 44^{\prime} \mathrm{E}$ and $53^{\circ} 55^{\prime} \mathrm{S} 108^{\circ} 55^{\prime} \mathrm{E}$ ), in the Australian sector (see Kölliker 1880: 23, Pl.X figs. 38-40). The interpretation 


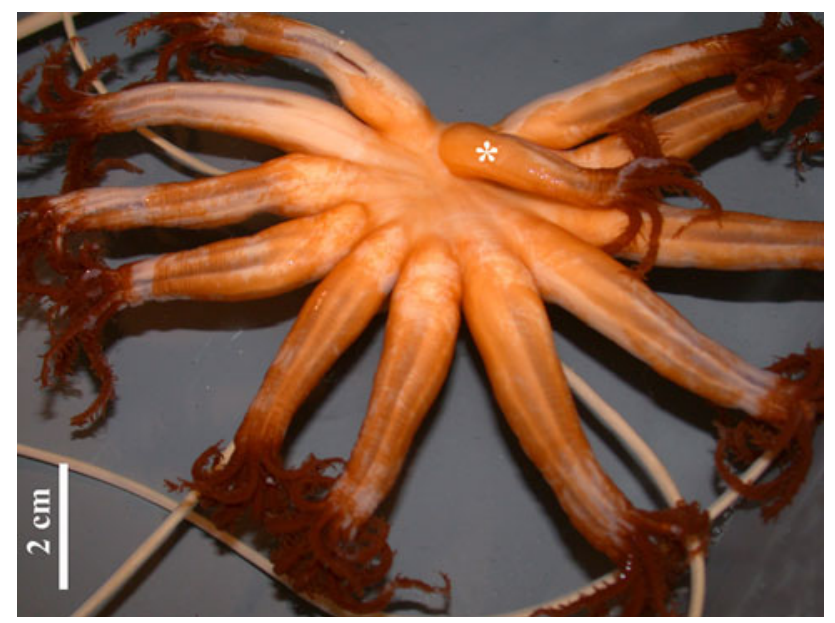

Fig. 8 Living colony of Umbellula carpenteri showing the bilaterally symmetrical, rosette-shaped polypary with eleven secondary polyps and the terminal polyp (asterisk) near the centre of the upper surface of the polypary. This specimen was collected in Antarctic waters $\left(71^{\circ} 18.47^{\prime} \mathrm{S} 13^{\circ} 58.53^{\prime} \mathrm{W}, 1,046-1,057 \mathrm{~m}\right.$ depth), during the ANDEEP-3 cruise

of the description given by Kölliker regarding the arrangement of the polyps was probably responsible for identification mistakes made by subsequent authors. It can be observed in the Kölliker's figures 38, 39 and 39a, as well as the description in the text, that Umbellula carpenteri is characterized by having "Polyps forming a rosette at the end of the stalk with an enlargement at its upper end". In the original description, the author mentions several times the presence of a "terminal polyp", and this could be interpreted as the terminal polyp present in chunellid genera such as Porcupinella gen. nov. However, the terminal polyp mentioned for Umbellula carpenteri is in the centre of a rosette of polyps disposed in a flattened plane (see Kölliker 1880: figs. 38a, 39; Pasternak 1962: figs. 2, 3a as Umbellula magniflora; Fig. 8 of the present paper), on the dorsal side of the colony (fig. 38b). It can be noticed that all secondary polyps are aligned in a single plane, and all polyps are clustered in a single congested polypary. This disposition is quite different from that described here for Porcupinella gen. nov. Even, the "large aberrant" Atlantic specimens illustrated by Broch (1957) or the South Indian specimens illustrated by Dolan (2008: p. 4) do not completely agree with Köllikler's description and illustration of $U$. carpenteri, although this should be studied in detail in a separate and future work.

Pasternak (1962: 125) already discussed the Atlantic material identified by Broch (1957) as Umbellula carpenteri, arriving to the conclusion that "all these colonies [the smallest ones] have nothing in common with U. magniflora [ $=U$. carpenteri for this author], a species which is characterized by a rosette of autozooids on the edge of a flattened rachis, whose upper surface does not bear secondary polyps.". Even, the "large aberrant" colonies of Broch (1957) are commented by Pasternak as not closely related to $U$, magniflora $(=U$. encrinus) by the presence of "autozooids at different levels".

Another question is whether Umbellula carpenteri and U. magniflora (both described by Kölliker 1880: pages 23 and 24, respectively) are synonymous. We agree with Pasternak (1962: 127) that $U$. carpenteri and U. magniflora are possibly the same species. However, the Russian authors prefer to use the later name considering that U. magniflora was used to describe "more mature specimens". Although that discussion is beyond the objectives of this paper, we believe that according to the rule of priority, the name Umbellula carpenteri should be retained as first described in Kölliker's text, which is perfectly recognizable in his Figures 38a and 38b.

Some comments on the possible phylogeny of chunellid taxa and their relationships with the family Umbelluliidae

According to current knowledge of the extant chunellid genera, the following morphological characters are useful to distinguish Amphiacme, Porcupinella and Chunella: (1) a conspicuous terminal zooid, which can be either fully developed or rudimentary, (2) the presence of pairs or whorls of polyps on the rachis and (3) the reduction in the space between pairs (or whorls) of autozooids on the rachis. Following the criteria used by Williams (1993, 1997) to produce the first assessment of the phylogeny of sea pens (Williams 1997: Table 1, Fig. 1), the number of usable characters in the group is somewhat limited, but they are enough to comment on some possible evolutionary lines in the family Chunellidae, mainly when we take into consideration the known geographical and bathymetric distribution of these genera.

Presuming the monophyly of the family by the following comments and considering as plesiomorphic the presence of a functional terminal zooid (in contrast to a reduced or practically absent one) and the paired biserial arrangement of autozooids along the rachis (in contrast to other modes of arrangements), our hypothetical ancestor could have a similar form to that of the present genus Amphiacme. It can be hypothesized that a rudimentary terminal polyp could be derived from a fully developed and functional one and that the clustering of polyps and terminal migration of polyps could be derived from paired polyps along the rachis. These hypothetical possibilities can be used to construct a topology for a cladogram of chunellid genera (Fig. 9). The presence of a functional terminal zooid and the paired placement of secondary zooids on the rachis locate Porcupinella close to Amphiacme. 


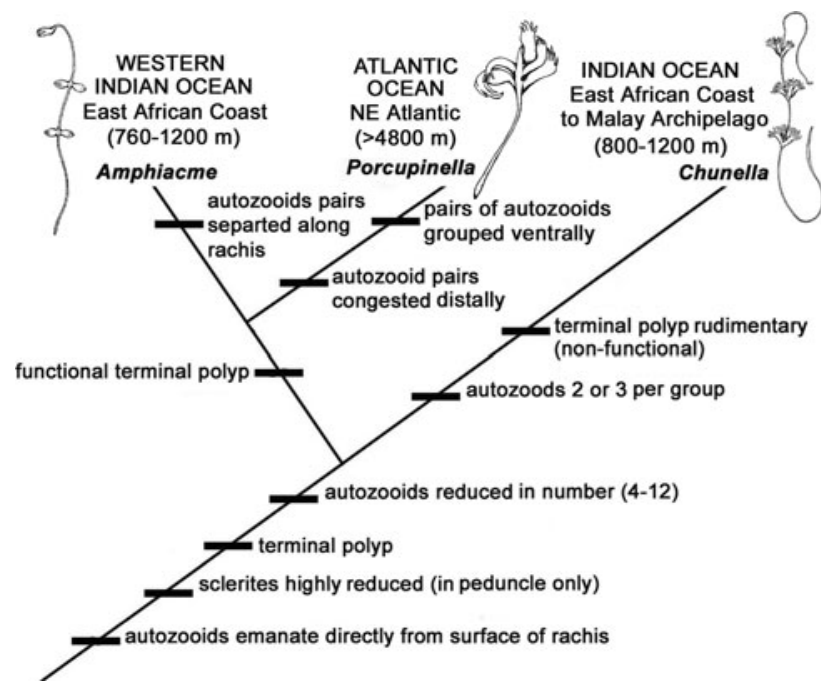

Fig. 9 Phylogeny and distribution of chunellid genera

Two possible hypotheses could explain the presence of members of this deep-sea pennatulacean family in both the Indian (Amphiacme and Chunella) and Atlantic oceans (Porcupinella): (1) the widespread distributional patterns of deep-sea fauna as is observed in other pennatulacean taxa (see Williams 1995a, b) and (2) the presence of a chunellid ancestor in the Tethys Sea [established from the Triassic (220-210 MA) and still present in the early Eocene (24-17 MA)], the wide connection between the young Atlantic and Indian Ocean. In this second hypothesis, dispersal processes were perhaps helped by the westward global equatorial Tethys current initiated in the middle Jurassic (ca 160 MA). Similar vicariant events have already been discussed to explain disjointed distributions in other marine invertebrate groups (Ho 1988). Fossil evidence considered with certitude as pennatulacean is limited to geologic time no earlier than the Cretaceous (Bayer 1956: 228).

In any of these scenarios, Chunella (eastern African coast to Malay archipelago, 800-1,200 $\mathrm{m}$ in depth) possibly originated in the Indian Ocean and dispersed eastwards. In this genus, a progressive reduction in the terminal zooid can be observed, the presence of whorls being an autapomorphy in the Chunella evolutionary line. Figure 9 summarizes the morphological changes and geographical and bathymetrical distributions for the chunellid genera discussed.

According to the ontogenetic stages of Umbellula encrinus illustrated in this paper, a possible "chunellid" connection can be observed in stages 1-2. The phylogenetic relationship between Umbellula and Chunella was already proposed in some of the first cladistic trees elaborated for pennatulaceans by Williams (1993, 1995b, 1997) and López-González and Williams (2002). However, the presence of sclerites is some of the species of Umbellula should be considered a plesiomorphic feature, in contrast to the absence of sclerites in all the chunellid genera (apomorphic). Thus, taking into account the abovementioned colonial morphological diversity and sclerite features in both families, if Umbelluliidae and Chunelliidae are closely related, it is more plausible to search for a common ancestor for both families than to consider the Umbellulidae as derived from the Chunellidae.

Acknowledgments Special thanks are addressed to Michel Segonzac and Jöelle Galéron (Ifremer, Centre de Brest) who made possible the study of the deep-sea anthozoans from the BENGAL cruises (EU MAST 3 programme, Marine Science and Technology programme 1994-1998). We thank the chief scientists: A.L. Rice (Challenger Division for Seafloor Processes, Southampton Oceanographic Centre, U.K.), B.J. Bett (Challenger Division for Sea floor Processes, Southampton Oceanographic Centre, U.K.), and M. Sibuet (IFREMER, Centre de Brest, DRO/Environnment Profond, France), the crew and scientific staff that participated in the different cruises for their invaluable technical and scientific assistance in the collection of specimens. The material of Umbellula encrinus examined for comparison was collected during the BIOICE project. We express our gratitude to Drs Gudmundur Vidir and Gudmundur Gudmundsson, and the staff of this project for making possible the study of the octocoral material at the Sandgerdi Marine Centre in Iceland. The author also acknowledges financial support for a visit to the Sandgerdi Marine Centre (Iceland) under the EC-funded TMR Large-Scale Facility Programme. The material of Umbellula carpenteri illustrated in Fig. 8 was collected during the ANDEEP 3 cruise. The authors acknowledge the valuable assistance of the officers and crew of the RV Polarstern and many colleagues on board during this cruise.

\section{References}

Balss H (1910) Japanische Pennatuliden. In: Doflein F (ed) Beiträge zur Naturgeschichte Ostasiens. Abh Math-phys Königlich Sächs Ges Wiss 1 (10 suppl):1-106

Bayer FM (1956) Octocorallia. In: Moore RC(ed) Treatise on invertebrate paleontology. Part F. Coelenterata. Geologial Society of America and the University of Kansas Press, Lawrence, pp 166-231

Bayer FM, Grasshoff M, Verseveldt J (1983) Illustrated trilingual glossary of morphological and anatomical terms applied to Octocorallia. E.J. Brill, Leiden

Broch H (1957) Pennatularians (Umbellula). Rep Swed Deep Sea Exped 1947-48 2(21):348-364

Dolan E (2008) Phylogenetic, systematics and biogeography of deepsea Pennatulacea (Anthozoa: Octocorallia). Evidences from molecules and morphology. Ph.D. Thesis, Univ Southampton $211 \mathrm{pp}$

Hickson SJ (1916) The Pennatulacea of the Siboga expedition, with a general survey of the order. Siboga Exped Monogr (14) $77: 1-265$

Ho JS (1988) Cladistics of Sunaristes, a genus of harpacticoid copepods associated with hermit crabs. Hydrobiologia 167-168: $555-560$

Jungersen HFE (1904) Pennatulida. Danish Ingolf Exped 5:1-95

Kükenthal W (1902) Diagnosen neuer Alcyonarien aus der Ausbeute der Deutschen Tiefsee-Expedition. Zool Anz 25:299-303

Kükenthal W (1903) Über eine neue Nephthyidengattung aus dem südatlantischen Ocean. Zool Anz 26:272-275 
Kükenthal W (1915) Pennatularia. Das Tierreich. Verlag von R. Friedländer und Sohn, Berlin

Kükenthal W, Broch H (1911) Pennatulacea. Wiss Ergebn Deutschen Tiefsee-Expedition "Valdivia" 13(1)2:113-576

Linnaeus C (1758) Systema naturae. Editio decima, reformata 1:1-824 (Holmiae)

López-González PJ, Williams GC (2002) A new genus and species of sea pen (Octocorallia: Pennatulacea: Stachytilidae) from the Antarctic Peninsula. Invertebr Syst 16:919-929

López-González PJ, Gili JM, Williams GC (2002) On some veretillid pennatulaceans from the eastern Atlantic and western Pacific Oceans (Anthozoan: Octocorallia), with a review of the genus Cavernularia, and descriptions of new taxa. J Zool 250:201-216

Nutting CC (1908) Descriptions of the Alcyonaria collected by the U.S. Bureau of Fisheries steamer 'Albatross' in the vicinity of the Hawaiian Islands in 1902. Proc US Nat Mus 34:543-601

Pasternak FA (1962) Pennatularia of the genus Umbellula Cuvier (Coelenterata, Octocorallia) from Antarctic and Subantarctic Waters. Biol rep Sov Antarct Exped (1955-1958) 1:107-130

von Kölliker RA (1880) Report on the Pennatulida dredged by H.M.S. Challenger during the years 1873-1876. Rep Scient Res Voyage of HMS. Challenger 1873-76. Zoology 1(2):1-41
Williams GC (1990) The Pennatulacea of southern Africa (Coelenterata, Anthozoa). Ann S Afr Mus 99(4):31-119

Williams GC (1993) Biotic diversity, biogeography and phylogeny of pennatulacean octocorals associated with coral reefs in the Indo-Pacific. In: Richmond RH (ed) Proceedings of service international CR symposium, 1992, vol 2. University of Guam Press, Mangilau, Guam, pp 729-735

Williams GC (1995a) Living genera of sea pens (Coelenterata: Octocorallia: Pennatulacea): illustrated key and synopses. Zool J Linn Soc 114:93-140

Williams GC (1995b) Preliminary assessment of the origin and phylogenetics of pennatulacean octocorals. Six Int Conf Coel Biol Prog Abst 102 (International Conference on Coelenterate Biology: Noordwijkerhout, The Netherlands)

Williams GC (1997) Preliminary assessment of the phylogeny of Pennatulacea (Anthozoa: Octocorallia), with a reevaluation of Ediacaran frond-like fossils, and a synopsis of the history of evolutionary thought regarding the sea pens. In: den Hartog JC (ed) Proceedings of sixth international conference on coel biology, 1995. Nationaal Natuurhistorisch Museum, Leiden, pp 497-509 